\title{
Onycholysis associated with green nail dyschromia
}

\section{Onycholiza powiązana z zielonym zabarwieniem paznokci}

\author{
Agnieszka Muth', Sara Królik', Honorata Kubisiak-Rzepczyk², Zygmunt Adamski³ , Dorota Jenerowicz ${ }^{3}$ \\ 'Students' Scientific Association at the Department of Dermatology, Poznan University of Medical Sciences, Poznan, Poland \\ 2Department of Dermatology and Venerology, Poznan University of Medical Sciences, Poznan, Poland \\ ${ }^{3}$ Chair and Department of Dermatology, Poznan University of Medical Sciences, Poznan, Poland \\ IStudenckie Koło Naukowe przy Katedrze i Klinice Dermatologii, Uniwersytet Medyczny w Poznaniu, Polska \\ 2Zakład Dermatologii i Wenerologii, Poznan Uniwersytet Medyczny w Poznaniu, Poland \\ ${ }^{3}$ Katedra i Klinika Dermatologii, Uniwersytet Medyczny w Poznaniu, Polska
}

\section{CORRESPONDING AUTHOR/ ADRES DO KORESPONDENCJI: dr hab. n. med. Dorota Jenerowicz Katedra i Klinika Dermatologii Uniwersytet Medyczny w Poznaniu ul. Przybyszewskiego 49 60-355 Poznań e-mail: djenerowicz@yahoo.com}

\begin{abstract}
Introduction. Green nail syndrome is a condition caused by the Pseudomonas aeruginosa infection. It is most often reported in patients with predisposing conditions that favour the growth of this pathogen such as constant exposure of the hands to water, soaps and detergents, especially in elderly persons.

Objective. The aim of this study is to present a case of the green nail syndrome in an elderly patient and bring attention to the greenish colour of the nails as a warning sign of the Pseudomonas aeruginosa infection.

Case report. An 88-year-old woman with asymptomatic green-yellowish changes on fingernail plates accompanied by onycholysis. The examination for fungal infection was negative, whereas the bacteriological culture of the nail was positive for Pseudomonas aeruginosa.

Conclusions. Green coloration of the nails should be a warning sign of the Pseudomonas aeruginosa infection. Treatment with oral ciprofloxacin, especially in elderly patients could be a valuable option for treating the green nail syndrome.
\end{abstract}

\section{STRESZCZENIE}

Wprowadzenie. Zespół zielonych paznokci wywoływany jest przez zakażenie bakterią Pseudomonas aeruginosa. Występuje najczęściej wśród pacjentów w podeszłym wieku, u których stwierdza się czynniki predysponujące do rozwoju tej jednostki chorobowej, takie jak stała ekspozycja rąk na wodę, środki myjące i detergenty.

Cel pracy. Celem pracy jest przedstawienie przypadku klinicznego zespołu zielonych paznokci u osoby w podeszłym wieku i zwrócenie uwagi na charakterystyczne zielonkawe zabarwienie paznokci jako objaw, który może wskazywać na zakażenie Pseudomonas aeruginosa.

Opis przypadku. Osiemdziesięcioośmioletnia pacjentka zgłosiła się z zielonożółtym zabarwieniem płytki paznokciowej na kilku palcach ręki. Objawowi temu towarzyszyła onycholiza. Wynik badania mykologicznego był ujemny, natomiast w hodowli bakteriologicznej uzyskano Pseudomonas aeruginosa. 
Wnioski. Zielone zabarwienie paznokci może wskazywać na zakażenie bakterią Pseudomonas aeruginosa. Skuteczną opcją terapeutyczną, szczególnie u osób starszych, może być stosowanie doustnych preparatów ciprofloksacyny.

Key words: onycholysis, Pseudomonas aeruginosa, elderly.

Słowa kluczowe: onycholiza, Pseudomonas aeruginosa, osoby w podeszłym wieku.

\section{INTRODUCTION}

Nail plate alterations are often observed in the elderly population and can be a sign of an infection or underlying systemic disease [1-4]. One of the most common nail disorders is fungal infection [5], but other pathogens should also be considered during the diagnostic process. Greenish discoloration of the nail plate was first described and linked to be caused by Pseudomonas aeruginosa by Goldman and Fox [4], hence this condition is named Goldman-Fox Syndrome (GFS) as well as chloronychia or green nail syndrome (GNS).

Pseudomonas aeruginosa is a Gram-negative, aerobic coccobacillus belonging to the Pseudomonadaceae family. Most of clinical isolates of this pathogen produce the blue-green pigments pyoverdin and pyocyanin [6]. Goldman and Fox postulated that an associated paronychia led to nail matrix spread with pigment diffusion through the nail plate to produce a bright green colour that ultimately transitioned to dull green [4]. Pseudomonas aeruginosa is not a part of physiological skin flora, so Pseudomonas infections of the intact nail are generally rare.

Onycholysis is a phenomenon of nail detachment from its bed and it may occur both in fingers and in toenails. It may be associated with particular dermatoses (i.e. psoriasis, onychomycosis), but appears also in subjects, whose hands are constantly exposed to water, soaps and other detergents, sometimes from occupational exposure [7]. Onycholysis may also be regarded as an age-related pathology and is frequently observed in the geriatric population [8].

\section{OBJECTIVE}

By this case report authors aimed to draw attention to co-appearance of onycholysis and greenish nail discoloration as an important indicator of $P$. aeruginosa infection, particularly when observed in an elderly patient.

\section{WPROWADZENIE}

Zmiany w obrębie płytek paznokciowych są często obserwowane $\mathrm{w}$ populacji osób $\mathrm{w}$ podeszłym wieku. Mogą być oznaką zakażenia albo układowej choroby podstawowej [1-4]. Do najczęstszych chorób paznokci należą zakażenia grzybicze [5], ale w procesie diagnostycznym należy uwzględniać także inne czynniki patogenne. Zielonkawe przebarwienie płytki paznokciowej jako objaw powiązany z zakażeniem bakterią Pseudomonas aeruginosa po raz pierwszy opisano w pracy Goldmana i Foxa (Pseudomonas aeruginosa) [4]. Dlatego też stan ten określany jest jako zespół Goldmana-Foxa (GFS), a także chloronychia lub zespół zielonych paznokci (ang. green nail syndrome - GNS).

Pseudomonas aeruginosa to Gram-ujemne bakterie tlenowe o kształcie pałeczek, należące do rodziny Pseudomonadaceae. Większość izolatów klinicznych tego patogenu wytwarza niebieskozielone barwniki: piowerdynę i piocyjaninę [6]. Według Goldmana i Foxa zanokcica wywoływana przez $P$. aeruginosa rozprzestrzenia się $\mathrm{w}$ macierzy paznokcia, czemu towarzyszy dyfuzja barwnika przez płytkę paznokciową. Wywołuje to żywozielone zabarwienie, które ostatecznie przekształca się w zgaszony odcień zieleni [4]. Pseudomonas aeruginosa nie należy do fizjologicznej flory bakteryjnej skóry, a zatem zakażenia nieuszkodzonych paznokci tą bakterią są na ogół rzadko obserwowane.

Onycholiza jest stanem, w którym dochodzi do odwarstwiania się płytki paznokcia od łożyska. Schorzenie może dotyczyć zarówno paznokci rąk, jak i stóp. Onycholiza może występować w przebiegu niektórych dermatoz (np. łuszczycy, grzybicy paznokci), ale pojawia się również u osób, których ręce są stale wystawione na działanie wody, mydła i innych detergentów, niekiedy w ramach narażenia zawodowego [7]. Onycholizę można również traktować jako patologiczny stan nasilający się z wiekiem, który jest często obserwowany w populacji geriatrycznej [8]. 


\section{CASE REPORT}

An 88-year-old generally healthy, retired female patient developed an asymptomatic green-yellowish discoloration of nail plates of several fingers within both hands. Toe nails were free of abnormalities. The patient mentioned that a similar episode took place a few years before and back then she was treated with a topical ointment which resulted in improvement of the nail condition, however the name of the medication is unknown. What is interesting, apart from green-yellowish discoloration of the nail plates, there was also marked onycholysis observed on other fingernail plates (fig. $1 \mathrm{~A}, \mathrm{~B}$ ). The patient reported that onycholysis preceded nail dyschromia and according to her observations, could possibly be associated with frequent use of various detergents and water during household works. Direct mycologic examination was performed, but it turned out negative thus did not confirm the fungal infection. However, the bacteriological culture of the nail was positive for $P$. aeruginosa (fig. 2). The patient was treated with oral ciprofloxacin in the dosage of $500 \mathrm{mg}$ twice a day for 7 days which caused gradual improvement of the condition.

\section{DISCUSSION}

The GNS is caused by the $P$. aeruginosa infection and it rarely involves intact nails. This condition is most often reported in patients with predisposing conditions that favour the growth of this pathogen, especially in elderly persons. According to literature data, onycholysis can be observed in almost $77 \%$ of patients infected with $P$. aeruginosa [9]. Separation of the nail from its bed creates a subungual space with accumulation of dirt, keratin and water which

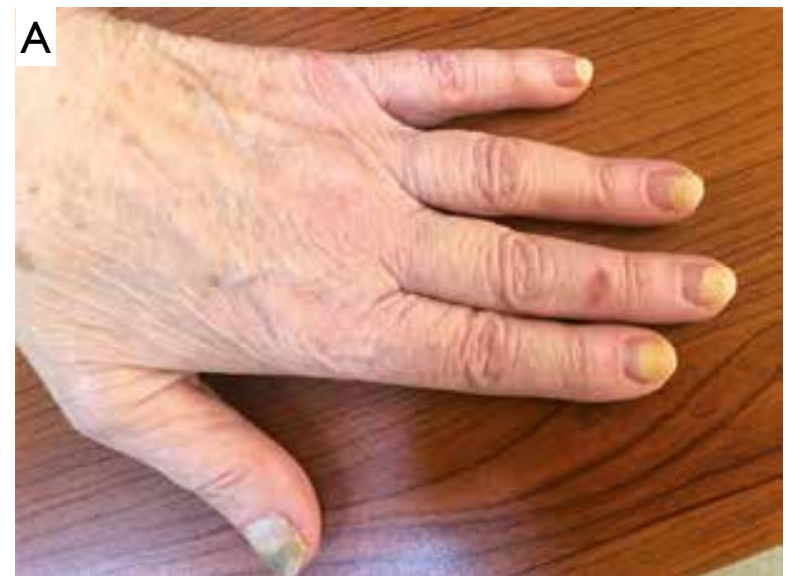

\section{CEL PRACY}

Opis przypadku ma na celu zwrócenie uwagi na współwystępowanie onycholizy i zielonkawego przebarwienia paznokci jako istotnego wskaźnika zakażenia bakterią P. aeruginosa, zwłaszcza u osób w podeszłym wieku.

\section{OPIS PRZYPADKU}

U 88-letniej, ogólnie zdrowej kobiety, emerytki, wystąpiło bezobjawowe zielonożółte przebarwienie płytek paznokciowych na kilku palcach obu rąk. Na paznokciach stóp nie stwierdzono żadnych nieprawidłowości. Pacjentka wspomniała, że podobne objawy wystąpiły u niej kilka lat wcześniej. Przepisano jej wówczas maść do stosowania miejscowego, która spowodowała poprawę stanu paznokci. Kobieta nie mogła sobie jednak przypomnieć nazwy leku. Zwraca uwagę fakt, że oprócz zielonożółtych przebarwień na innych płytkach paznokci rąk zaobserwowano również onycholizę (ryc. 1 A, B). Pacjentka podała, że onycholiza poprzedzała wystąpienie dyschromii paznokci, a z jej własnych obserwacji wynika, że objaw ten może być związany z częstym stosowaniem różnych detergentów i wody podczas prac domowych. Wykonano bezpośrednie badanie mykologiczne, które dało wynik ujemny, wykluczając zakażenie grzybicze. Posiew bakteriologiczny materiału pobranego z paznokcia był dodatni w kierunku zakażenia $P$. aeruginosa (ryc. 2). Wdrożono doustne leczenie ciprofloksacyną $\mathrm{w}$ dawce $500 \mathrm{mg}$ dwa razy na dobę przez 7 dni, które przyniosło stopniową poprawę.

\section{OMÓWIENIE}

Zespół zielonych paznokci jest zaburzeniem spowodowanym przez zakażenie bakterią P. aeruginosa i rzad-

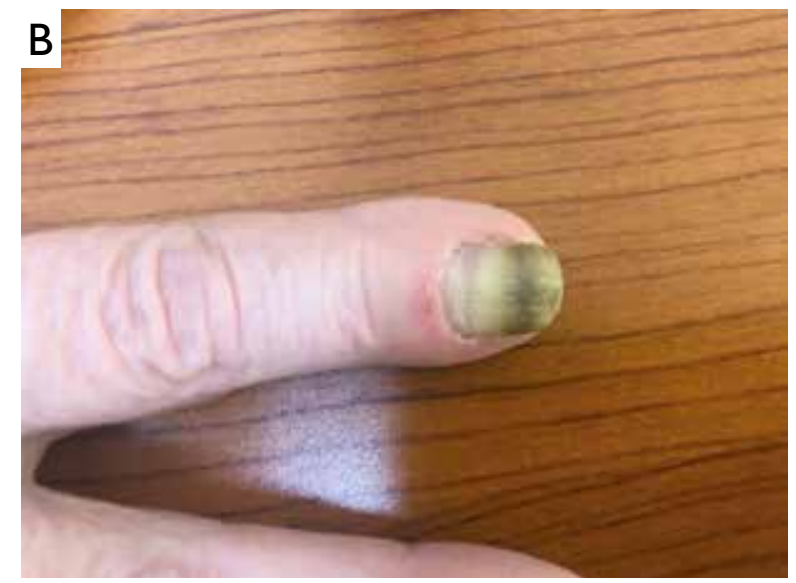

Figure I. A - Marked onycholysis of fingernails 2-4 and greenish discoloration of a thumbnail (left hand). B - Yellowish-green dyschromia of the right hand index fingernail

Rycina I. A - Nasilona onycholiza paznokci palców 2-4 i zielonkawe zabarwienie paznokcia kciuka (ręka lewa). B - Zielonożółta dyschromia paznokcia palca wskazującego ręki prawej 


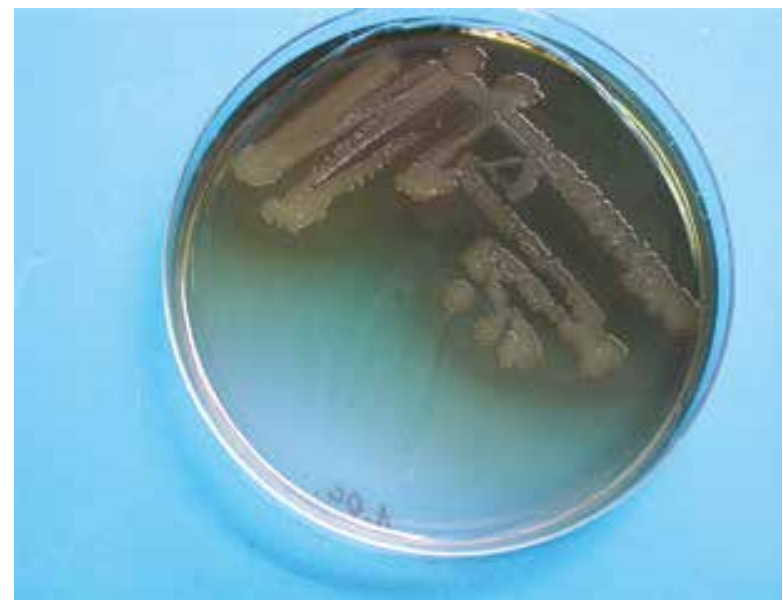

Figure 2. Positive bacterial culture towards Pseudomonas aeruginosa

Rycina 2. Dodatni wynik hodowli bakteryjnej w kierunku Pseudomonas aeruginosa

in consequence enables microorganisms to colonize this accessible area. Finger onycholysis is most common in female patients and $P$. aeruginosa is frequently isolated - possibly due to transfer during hygienic practices of intimate areas $[10,11]$.

\section{CONCLUSIONS}

The GNS may be treated with antiseptics and antibiotics, in monotherapy or in combination. It is worth emphasizing that $P$. aeruginosa shows natural resistance to numerous antibiotics. Those of antipseudomonal activity include aminoglycosides, quinolones, certain cephalosporins, carbapenems and antipseudomonal penicillins [12]. To minimize onycholysis it is important to keep the nails dry and short and to avoid frequent use of nail polish, soaps and other detergents [10].

\section{CONFLICT OF INTEREST}

The authors declare no conflict of interest. ko dotyczy nieuszkodzonych paznokci. Najczęściej występuje u pacjentów z chorobami, które sprzyjają rozwojowi tego patogenu, występującego u osób starszych. Według danych z literatury u blisko $77 \%$ pacjentów zakażonych P. aeruginosa obserwuje się onycholizę [9]. Odwarstwienie się płytki paznokcia od łożyska powoduje powstawanie przestrzeni podpaznokciowej, w której gromadzą się zanieczyszczenia, keratyna i woda, umożliwiając mikroorganizmom kolonizację tego łatwo dostępnego obszaru. Onycholiza paznokci palców rąk występuje zazwyczaj u kobiet, a w badaniach często izolowana jest bakteria $P$. aeruginosa, prawdopodobnie na skutek jej przenoszenia podczas czynności higienicznych w okolicach intymnych $[10,11]$.

\section{WNIOSKI}

W leczeniu GNS można stosować środki antyseptyczne i antybiotyki, w monoterapii lub leczeniu skojarzonym. Warto podkreślić, że bakterie P. aeruginosa wykazują naturalną odporność na wiele antybiotyków. Zdolność zwalczania P. aeruginosa mają aminoglikozydy, chinolony, niektóre cefalosporyny, karbapenemy oraz penicyliny wykazujące aktywność wobec tej bakterii [12]. Aby zminimalizować ryzyko onycholizy, paznokcie powinny być suche i krótkie. Należy także unikać częstego stosowania lakierów do paznokci, mydeł i innych detergentów [10].

\section{KONFLIKT INTERESÓW}

Autorzy nie zgłaszają konfliktu interesów.

\section{References}

Piśmiennictwo

1. Witkowski A., Jasterzbski T., Schwartz R.A.: Terry's nails: A sign of systemic disease. Indian J Dermatol 2017, 62, 309-311. 2. Almohssen A., Schwartz R.A.: Rubronychia: a rose by any other name. J Eur Acad Dermatol Venereol 2019, 33, e103-104. 
3. Schwartz R.A., Barnett C.: Muehrcke lines of the fingernails: background, pathophysiology, etiology, 2019. Available from: https://emedicine.medscape.com/article/1106423-overview. Updated: May 17, 2020.

4. Goldman L, Fox H.: Greenish pigmentation of the nail plates from bacillus pyocyaneus infection. AMA Arch Dermatol Syphilol 1944, 68, 136-137.

5. Muth C.C.: Fungal nail infection. JAMA 2017, 317, 546.

6. Pier G., Ramphal R.: Pseudomonas aeruginosa. [In:] Principles and Practice of Infectious Diseases. 6th ed. G.L. Mandell, J.E. Bennett, R. Dolin (eds.). Churchill Livingstone, Philadelphia, 2004, 2587-2615.

7. Schwartz R.A., Reynoso-Vasquez N., Kapila R.: Chloronychia: the Goldman-Fox syndrome - implications for patients and healthcare workers. Indian J Dermatol 2020, 65, 1-4.

8. Singh G. Nail changes and disorders among the elderly. Indian J Dermatol Venereol Leprol 2005, 7, 386-392.

9. Geizhals S., Lipner S.R.: Retrospective case series on risk factors, diagnosis and treatment of Pseudomonas aeruginosa nail infections. Am J Clin Dermatol 2020, 21, 297-302.

10. Chang P., Vascuez-Acajabon M.V.: Onycholysis due to trauma. Our Dermatol Online 2014, 5, 201-204.

11. Zaias N., Escovar S.X., Zaiac M.N.: Finger and toenail onycholysis. J Eur Acad Dermatol Venereol 2015, 29, 848-853.

12. Cunha B.A.: Pseudomonas aeruginosa: resistance and therapy. Semin Respir Infect 2002, 17, 231-239.

Received: 24.06 .2020

Accepted: 7.10.2020

Otrzymano: $24.06 .2020 \mathrm{r}$.

Zaakceptowano: $7.10 .2020 \mathrm{r}$.

How to cite this article

Muth A., Królik S., Kubisiak-Rzepczyk H., Adamski Z., Jenerowicz D.: Onycholysis associated with green nail dyschromia a case report. Dermatol Rev/Przegl Dermatol 2020, 107, 546-550. DOI: https:/ /doi.org/10.5114/dr.2020.103890 